\title{
THE LEGACY OF RONALD DWORKIN (1931-2013): A LEGAL THEORY AND METHODOLOGY FOR HEDGEHOGS, HERCULES, AND ONE RIGHT ANSWERS*
}

\author{
EL LEGADO DE RONALD DWORKIN (1931-2013): \\ UNA TEORIA Y METODOLOGIA JURIDICA PARA ERIZOS, HÉRCULES, Y \\ LAS ÚNICAS RESPUESTAS CORRECTAS
}

\author{
Imer B. FLORES**
}

\begin{abstract}
Resumen:
En este articulo el autor examina la obra de Ronald Dworkin y evalúa su legado para la filosofia juridica, moral y política. Asi, considera entre sus méritos el haber desarrollado una teoría juridica original con su metodologia distintiva, la cual no solamente ha trascendido la dicotomia entre derecho natural y positivismo jurídico, sino además ha reintegrado al derecho como una rama de la moralidad politica y defendido como corolario

* Artículo recibido el 15 de noviembre de 2014 y aceptado para su publicación el 28 de noviembre de 2014 .

** Professor-Researcher, Instituto de Investigaciones Juridicas and Facultad de Derecho, UNAM. Email: imer@unam.mx. I am grateful to Edgar Aguilera, Catarina Barbieri, Andrés Botero, Luka Burazin, Enrique Cáceres, Tom Campbell, Pierluigi Chiassoni, Juan Antonio Cruz Parcero, Luis Duarte D'Almeida, Kenneth E. Himma, Miodrag Jovanović, Andrei Kristian, Dimitrios Kyritsis, Diego E. López Medina, Ronaldo Macedo, Antonio O. Piccato Rodríguez, Dan Priel, Luciana Reis, Adriân Renteria, Germán M. Sandoval Trigo, Burkhard Schafer, Fred Schauer, Michael Seidman, Fábio Shecaira, Noel Struchiner, Bojan Spaić, Gülriz Uygur, Guillermo Gabino Vázquez Robles, and Juan M. Vega Gómez for their comments and questions on the previous versions (or parts) and presentations, which have been very extremely helpful in order to clarify my thoughts and to refine my argument, and especially to Ken Himma for his public commentary to the version presented at the McMaster Conference.
\end{abstract}


Este libro forma parte del acervo de la Biblioteca Jurídica Virtual del Instituto de Investigaciones Jurídicas de la UNAM

IMER B. FLORES

la tesis de la única respuesta correcta. De esta forma, comienza por identificar el desafio dworkiniano; continúa al introducir algunas definiciones y distinciones básicas entre jurisprudencia, filosofia jurídica (o filosofia del derecho) y teoría jurídica (o teoría del derecho), de un lado, y su relación con la metodología, del otro; después al apuntar las diferentes metodologías disponibles a las teorias jurídicas, a partir de las distinciones tanto entre descriptiva y prescriptiva o normativa, por una parte, como entre general y particular, por la otra; luego al revisitar el modelo de Dworkin, mismo que caracteriza como constructivo, interpretivo (e inclusive argumentativo), evaluativo e integrativo; y, concluye al reconsiderar en esta luz la tesis de la única respuesta correcta.

\title{
Palabras clave:
}

Teoría jurídica y metodología, modelo argumentativo, constructivo, evaluativo, integrativo e interpretivo, tesis de la única respuesta correcta, Ronald Dworkin.

\begin{abstract}
:
In this paper the author addresses Ronald Dworkin's work and assesses his legacy to legal, moral and political philosophy. And so, considers among its merits having developed an original legal theory with its distinctive methodology, which not only has transcended the Natural Law and Legal Positivism dichotomy, but also has reintegrated law into a branch of political morality and defended as a corollary the one right answer thesis. Hence, commences by identifying the dworkininan challenge; continues by introducing some basic definitions and distinctions between jurisprudence, legal philosophy (or philosophy of law) and legal theory (or theory of law), on the one hand, and its relationship to methodology, on the other hand; later by pointing out the main methodologies available to legal theories, following the distinctions between descriptive and prescriptive or normative, on one side, and, general and particular, on the other; then by revisiting Dworkin's model, which he characterizes as constructive, interpretive (and even argumentative), evaluative and integrative; and, concludes by reconsidering in this light the one right answer thesis.
\end{abstract}

Keywords:

Legal Theory and Methodology, Argumentative, Constructive, Evaluative, Integrative, and Interpretive Models, One Right Answer Thesis, Ronald Dworkin. 


\section{THE LEGACY OF RONALD DWORKIN}

For all practical purposes, there will always be a right answer in the seamless web of our law.

Ronald DwORKIN, 'No Right Answer?' (1977).

This "no right answer" thesis cannot be true by default in law any more than in ethics or aesthetics or morals.

Ronald DwORKIN, 'Objectivity and Truth: You'd Better Believe It’ (1996).

Sheldon: What is the best number? By the way, there's only one correct answer.

Raj: 5,318,008?

Sheldon: Wrong! The best number is 73. [Short silence] You're probably wondering why?

Leonard: No.

Howard: Uh-uh.

Raj: We're good.

Sheldon: 73 is the 21st prime number. Its mirror, 37, is the 12th, and its mirror, 21, is the product of multiplying, hang on to your hats, 7 and 3. Heh? Heh? Did I lie?

Leonard: We get it! 73 is the Chuck Norris of numbers!

Sheldon: Chuck Norris wishes! In binary, 73 is a palindrome, 1-0-0-1-0-0-1, which backwards is 1-0-0-1-0-0-1, exactly the same. All Chuck Norris backwards gets you is "Sirron Kcuhc".

Raj: Just for the record, when you enter 5,318,008 in a calculator, upside-down it spells "boobies".

The Big Bang Theory, "The Alien Parasite Hypothesis", Series 4, Episode 10 (2010).

Summary: I. Introduction. II. Definitions and Distinctions. III. Legal Theories and Methodologies. IV. Dworkin's Legal Theory and Methodology. V. Dworkin's One Right Answer Thesis Reconsidered. VI. References.

\section{INTRODUCTION}

Addressing Ronald Dworkin's work and assessing his legacy are the main aims of this paper. Let me point out in advance that in my opinion he is the greatest legal philosopher and theorist ever and is among the most influential 
moral and political philosopher of our time. In a few words, he developed an original legal theory with its distinctive methodology, which not only has transcended the Natural Law and Legal Positivism dichotomy, but also has reintegrated law into a branch of political morality and defended as a corollary the one right answer thesis.

As advanced in the "Introduction" to his celebrated Taking Rights Seriously he aimed to "define and defend a liberal theory of law" by being sharply critical of another theory widely thought to be liberal, i.e. the "ruling theory of law", which "has two parts and insists on their independence". The first part is a "theory about what law is", i.e. "the theory of legal positivism, which holds that the truth of legal propositions consists in facts about rules that have been adopted by specific social institutions, and in nothing else." The second is a "theory about what the law ought to be", i.e. "the theory of utilitarianism, which holds that law and its institutions should serve the general welfare, and nothing else." 1

Contrary to the insistence about the independence of both parts, he claims: "A general theory of law must be normative as well as conceptual."2 Bear in mind that this claim will allow Dworkin to collapse the distinction between descriptive and prescriptive: ${ }^{3}$

Its normative part must treat a variety of topics indicated by the following catalogue. It must have a theory of legislation, of adjudication, and of compliance; these three theories look at the normative questions of law from the standpoint of a lawmaker, a judge, and an ordinary citizen. The theory of legislation must contain a theory of legitimacy, which describes the circumstances under which a particular person or group is entitled to make law, and a theory of legislative

1 Ronald Dworkin, Taking Rights Seriously (Harvard UP \& Duckworth 1977; 2nd edn 'with an "Appendix: A Reply to Critics"', Harvard UP \& Duckworth 1978) vii.

2 Ibid.

3 Ibid vii-viii (emphasis added). 


\section{THE LEGACY OF RONALD DWORKIN}

justice, which describes the law they are entitled or obliged to make. The theory of adjudication must also be complex: it must contain a theory of controversy, which sets out standards that judges should use to decide hard cases at law, and a theory of jurisdiction, which explains why and when judges, rather than other groups or institutions, should make the decisions required by the theory of controversy. The theory of compliance must contrast and discuss two roles. It must contain a theory of deference, which discusses the nature and limits of the citizen's duty to obey the law in different forms of state, and under different circumstances, and a theory of enforcement, which identifies the goals of enforcement and punishment, and describes how official should respond to different categories of crime or fault.

In a few words, he connects or even - as I will argue- integrates both parts, i.e. the normative and the conceptual, not only within a general theory of law but also with other departments of philosophy. In his own voice: ${ }^{4}$

The interdependencies of the various parts of a general theory of law are therefore complex. In the same way, moreover, a general theory of law will have many connections with other departments of philosophy. The normative theory will be embedded in a more general political and moral philosophy which may in turn depend upon philosophical theories about human nature or the objectivity of morality. The conceptual part will draw upon the philosophy of language and therefore upon logic and metaphysics... A general theory of law must therefore constantly take up one or another disputed position on problems of philosophy that are not distinctly legal.

In short, Dworkin's powerful critique of law as a model or system of rules and of legal positivism as a form of legal conventionalism, as well as his conception of law as constructive interpretation, as a chain novel, as integrity, as an interpretive concept, and as a branch of political morality,

4 Ibid viii-ix. 
IMER B. FLORES

among many other features of his theory, challenged not only the then clearly dominant legal theory but also its methodology, which claims to be general and descriptive or even indirectly evaluative but still morally neutral. ${ }^{5}$

Hence, after identifying Dworkin's challenge, including the existence of persistent and pervasive disagreements within the different legal theories that arguably describe the same phenomenon, ${ }^{6}$ but that actually prescribe a different solution to it, I intend: in section II, to introduce some basic definitions and distinctions between jurisprudence, legal philosophy (or philosophy of law) and legal theory (or theory of law), on one side, and its relationship to methodology, on the other; in section III, to point out the main methodologies available to legal theories; in section IV, to revisit Dworkin's model; and, finally, in section V, to conclude by briefly reconsidering the one right answer thesis.

\section{Definitions AND Distinctions}

The aim of this section is: first, to introduce some basic definitions and distinctions between "jurisprudence", "legal philosophy" or "philosophy of law", and "legal theory" or "theory of law"; and, second, to point out their relations to the so-called "legal methodology" (or "methodology", for short). Although the terms "jurisprudence", "legal philoso-

5 See for the early version Ronald Dworkin, 'The Model of Rules' (1967) 35 University of Chicago Law Review 14 (reprinted as 'Model of Rules I' in Dworkin (n 1); references will be made to this version); Ronald Dworkin, 'Social Rules and Legal Theory' (1972) 81 Yale Law Journal 855 (reprinted as 'Model of Rules II' in Dworkin (n 1); references will be made to this version); and Ronald Dworkin, 'Hard Cases' (1974) 88 Harvard Law Review 1057 (reprinted in Dworkin (n 1); references will be made to this version), as well as the other essays reprinted or published originally in Dworkin (n 1); see for the later version, Ronald Dworkin, Law's Empire (Harvard University Press 1986); and for the latest version Ronald Dworkin, Justice for Hedgehogs (Harvard University Press 2011).

6 See Dan Priel, 'Jurisprudential Disagreements and Descriptivism' (2014) 8 Problema. Anuario de Filosofia y Teoría del Derecho 483. 
phy" or "philosophy of law", and "legal theory" are used more or less interchangeably, I will like to point out that the different labels are helpful in order to figure out the underlying "methodology", including its scientific, philosophical and theoretical presumptions and presuppositions. ${ }^{7}$

Since Roman times, following the famous definitions, placed in a passage at the beginning of the Digest of Justinian, by Ulpian "Iurisprudentia est divinarum atque humanarum rerum notitia, iusti atque iniusti scientia" (i.e. "Jurisprudence is the knowledge of things divine and human; the science of the just and unjust"), and by Celso "Ius est ars boni et requi" (i.e. "Law is the art of the good and fair"), the word "jurisprudence" denotes the scientific knowledge of "law", which is its object or subject-matter. ${ }^{8}$

Curiously, John Austin in The Uses of the Study of Jurisprudence (1863), published thirty-one years after The Province of Jurisprudence Determined (1832), on the one hand, cautioned that the word "Jurisprudence itself is not free from ambiguity", since it has been used to denote both "The knowledge of Law as a science" and of "Legislation... as the science of what ought to be done towards making good

7 In this section, I am following Larry Solum, 'Legal Theory Lexicon 044: Legal Theory, Jurisprudence, and the Philosophy of Law', in Legal Theory Lexicon http://lsolum.typepad.com/legal_theory_lexicon/2003/ 44/legal_theory_le.html and http://legaltheorylexicon.blogspot.com/ 2005/05/legal-theory-lexicon-044-legal-theory.html accessed 14 November 2014 .

8 John Austin uses this passage from the Roman jurists as an example of the " 2 nd.Tendency to confound positive law with positive morality, and both with legislation and deontology" but nevertheless affirms: "jurisprudence... is the science of law", see "The Province of Jurisprudence Determined' (first published 1832) in The Province of Jurisprudence Determined and The Uses of the Study of Jurisprudence (Hackett Publishing 1998) Lecture V, 188-90; see ibid 189: "Now jurisprudence, if it is anything, is the science of law, or at most the science of law combined with the art of applying it; but what it here given as a definition of it, embraces not only law, but positive morality, and even the test to which both these are to be referred. It therefore comprises the science of legislation and deontology." 
laws", but, on the other hand, apparently conceded: "With us, Jurisprudence is the science of what is essential to law, combined with the science of what ought to be." Nevertheless, the word "jurisprudence" is used to refer to a science (or part of it), as well as to the scientific knowledge of "law".

Whereas the expressions "legal philosophy" or "philosophy of law" by using the word "philosophy" suggest that the distinctive knowledge (or at least the method) is not scientific per se but philosophical, irrespective of whether there is a close or not relationship between science and philosophy, following the adagio: "philosophy is the mother of all sciences". The fact that both jurisprudence and legal philosophy or philosophy of law, during the XIX and XX centuries, were done all over the world exclusively by lawyers (or jurists), without a formal degree on philosophy, reinforced the view that the terms where used - or at least can be used- interchangeably. This fact remained unchallenged until H.L.A Hart, a philosopher by formation, who at some point planned to become an barrister and hence was studying for the bar before joining M15 during the Second World War, started —as Nicola Lacey put it_ "Selling Philosophy to Lawyers" as "The Chair of Jurisprudence" in Oxford.10 Though I am absolutely convinced that Hart sold analytic or linguistic philosophy to lawyers, he did still used the terms more or less interchangeably, but certainly with a clear and distinctive philosophical emphasis. ${ }^{11}$ In that

9 John Austin, "The Uses of the Study of Jurisprudence" (first published 1863) in Austin (n 8) 372 (emphasis original).

10 See Nicola Lacey, A Life of H.L.A. Hart. The Nightmare and the Noble Dream (Oxford University Press 2004) 155-78.

11 See HLA Hart, The Concept of Law (Oxford University Press 1961; 2nd edn "With a "Postscript" edited by Penelope A. Bulloch and Joseph Raz', Oxford University Press 1994; and 3rd edn 'With an "Introduction and Notes" by Leslie Green', Oxford University Press 2012); see also HLA Hart, Law, Liberty and Morality (Stanford University Pres, 1963); HLA Hart, Punishment and Responsability. Essays in the Philosophy of Law (Oxford University Press 1968); HLA Hart, Essays on Bentham. Jurispru- 
sense, I am not completely persuaded that the usage of "jurisprudence" is reserved for law schools or lawyers (or jurists) and "legal philosophy" or "philosophy of law" for philosophy departments or philosophers. ${ }^{12}$ From my point of view the relevant distinction is whether "jurisprudence" and "legal philosophy" or "philosophy of law" is done by lawyers (or jurists) or by philosophers. Ideally, it should be done both by lawyers (or jurists) with a philosophical background and by philosophers with a legal one.

Finally, the terms "legal theory", "theory of law" and even "theory about law" are much more broader by encompassing not only "jurisprudence" and "legal philosophy" or "philosophy of law" but also theorizing from a variety of other perspectives, including "law and economics", "law and politics", "law and literature", "law and society", as well as critical approaches, and so on. ${ }^{13}$ To the extent, that Solum affirms that "legal theory" is "currently the best neutral term for referring to legal theorizing, broadly understood."14 Nonetheless, since there is not a one and only method of theorizing about law, let me suggest that there are several methodologies and hence legal theories.

\section{LEgAL TheORIES AND METhodologies}

Let me start this section by quoting H.L.A. Hart's clarification of the aims of his legal theory and its basic methodological presumptions and presuppositions in the "Postscript" to The Concept of Law: 15

dence and Political Theory (Oxford University Press 1982); and, HLA Hart, Essays in Jurisprudence and Philosophy (Oxford University Press 1983).

12 Cf Solum (n 7) affirming that Hart "had a dominant influence in defining the content of courses on philosophy of law in philosophy departments and jurisprudence in law schools"

13 See, for example, Brian Bix, Jurisprudence: Theory and Context (3rd edn, Sweet \& Maxwell 2003).

14 See Solum (n 7) (emphasis original).

15 HLA Hart, "Postscript", in Hart (n 11) 239-40. 
My aim in this book was to provide a theory of what law is which is both general and descriptive. It is general in the sense that it is not tied to any particular legal system or legal culture, but seeks to give an explanatory and clarifying account of law as a complex social and political institution with a rule-governed (and in that sense 'normative') aspect... My account is descriptive in that it is morally neutral and has no justificatory aims: it does not seek to justify or commend on moral or other grounds the forms and structures which appear in my general account of law, though a clear understanding of these is, I think, an important preliminary to any useful moral criticism of law.

At the outset of the clarification, we can identify two basic methodological distinctions as applied to legal theories:

1) The distinction between general legal theories that respond to "questions about what is common to all legal systems and cultures" and particular legal theories that respond to "questions about what is specific to a legal system or culture"; 16 and

2) The distinction between descriptive legal theories with explanatory aims that respond to "questions about what the law is" or "questions about facts"; and normative legal theories with justificatory aims that respond to "questions about what the law ought to be" or "questions about values". ${ }^{17}$

16 The distinction between "general and particular jurisprudence" can be traced all the way back to Austin, see Austin (n 9) 372: "Particular [or National] Jurisprudence is the science of any actual system of law, or of any portion of it." See ibid 373: "The proper subject of General or Universal Jurisprudence... is a description of such subjects and ends of Law as are common to all systems"; cf Jeremy Bentham, An Introduction to the Principles of Morals and Legislation (first published 1789, JH Burns and HLA Hart eds, Oxford University Press 1996) Chapter XVII, §§ 21-9, 293-300 (referring to the different branches of jurisprudence and using the parallel distinctions between "universal and internal, local, national, particular or provincial jurisprudence").

17 I am not only following Julie Dickson, Evaluation and Legal Theory (Hart Publishing 2001) 1-28, and 29-49, but also adapting Hart's distinc- 


\section{THE LEGACY OF RONALD DWORKIN}

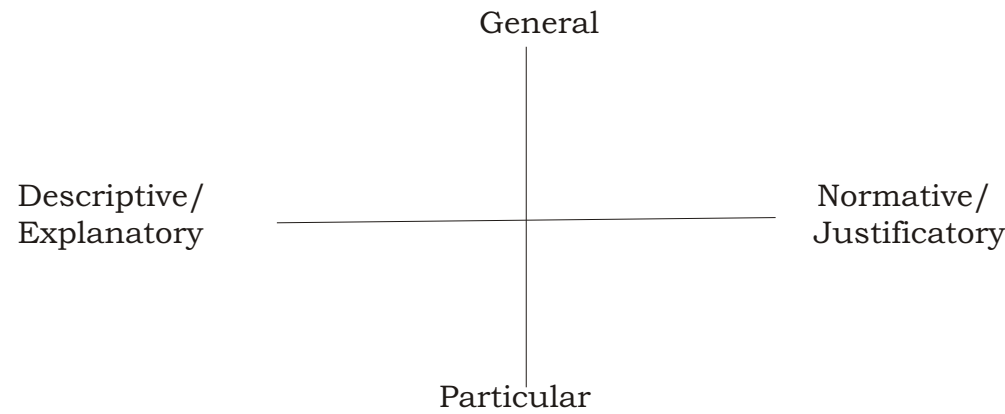

tion between "descriptive / explanatory and normative / justificatory legal theory", Hart (n 15) 239-40, which is parallel to Bentham's "expository and censorial jurisprudence", see Bentham (n 16) Chapter XVII, § 21, 293-4: "A book of jurisprudence can have but one or the other of two objects: 1 . to ascertain what the law is: 2 . to ascertain what it ought to be. In the former case it may be styled a book of expository jurisprudence; in the latter, a book of censorial jurisprudence" (emphasis original), see also Jeremy Bentham, A Fragment on Government (first published 1776, JH Burns and HLA Hart eds, Cambridge University Press 1988) 7: “There are two characters, one or other of which every man who finds any thing to say on the subject of Law, may be said to take upon him; - that of the Expositor, and that of the Censor. To the province of the Expositor it belongs to explain to us what, as he supposes, the Law is: to that of the Censor, to observe to us what he thinks it ought to be. The former, therefore, is principally occupied in stating, or in enquiring after facts: the latter, in discussing reasons." cf Hart, Essays on Bentham... (n 11) 1-2, 41 and 137.

However, I am also adopting both Arthur Ripstein's distinction between "normative and analytic jurisprudence", see "Normative and Analytic Jurisprudence', in IVR Encyclopaedia of Jurisprudence, Legal Theory and Philosophy of Law http://www.ivr-enc.info/index.php?title= Normative_and_Analytic_Jurisprudence accessed 14 November 2014; and, Larry Solum's distinction between "positive and normative legal theory”, see 'Legal Theory Lexicon 016: Positive and Normative Legal Theory', in Legal Theory Lexicon http://1solum.typepad.com/legal_theory_lexicon/2003/12/legal_theory_le.html accessed 14 November 2014.

In Solum's terminology "Positive legal theory seeks to explain what the law is and why it is that way, and how laws affect the world, whereas Normative legal theories tell us what the law ought to be... Or more simply: positive legal theories are about facts and normative legal theories are about values." 
Furthermore, the clarification suggests that since there are there two axis - the one distinguishing general and particular legal theories, and the other descriptive / explanatory and normative / justificatory legal theories - there are four resulting quadrants that correspond to four initial possibilities: (1) general and descriptive / explanatory legal theories; (2) general and normative / justificatory legal theories; (3) particular and descriptive / explanatory legal theories; and (4) particular and normative / justificatory legal theories. Moreover, nothing precludes a more comprehensive legal theory that includes more than one quadrant and that correspond to four additional possibilities combining: (1) and (2); (3) and (4); (1) and (3); and (2) and (4); and, even a much more comprehensive theory that integrates the four quadrants and a further possibility combining: (1), (2), (3), and (4). ${ }^{18}$

\begin{tabular}{|c|c|c|}
\hline & Descriptive/Explanatory & Normative/Justificatory \\
\hline General & (1) & (2) \\
\hline Particular & (3) & (4) \\
\hline
\end{tabular}

Traditionally, natural law theories do accept and even embrace the normative dimension to the extent that they appear to be clearly justificatory, whereas positive law theories reject it by claiming to remain (purely or solely) descriptive, to the extent that they are explanatory.

18 Let me advance that for the purposes of this paper, I am especially interested in the possibility of connecting (1) "general descriptive / explanatory legal theory" and (2) "general normative / justificatory legal theory", on the one hand, and (3) "particular descriptive / explanatory legal theory" and (4) "particular normative / justificatory legal theory", on the other hand, and even the possibility of contrasting (1) and (3), on one side, and (2) and (4), on the other. The only two options that I do not consider feasible because they will turn out to be logically fallacious are connecting: (1) and (4); and (2) and (3); and, hence, they are completely ruled out. 


\section{THE LEGACY OF RONALD DWORKIN}

On the one hand, additionally to Hart, John Austin and Hans Kelsen as well as other positive law theorists, i.e. legal positivists, are representative of (1). For example, Austin famously appealed: "The existence of law is one thing; its merit or demerit is another. Whether it be or not be is one enquiry; whether it be or nor be conformable to an assumed standard, is a different enquiry. A law, which actually exists, is a law, though we happen to dislike it, or though it vary from the text, by which we regulate our approbation and disapprobation."19 Analogously, Kelsen -at the beginning of both editions of his Reine Rechstlehre- asserted:20

The Pure Theory of Law is a theory of positive law. It is a theory of positive law in general, not of a specific legal order. It is a general theory of law, not an interpretation of specific national or international legal norms; but it offers a theory of interpretation.

As a theory, its exclusive purpose is to know and to describe its object. The theory attempts to answer the question what and how the law is, not it ought to be. It is a science of law (jurisprudence), not legal politics.

On the other hand, certainly Saint Augustine of Hippo and other classical natural law theorists are representative of (2) since they appear to hold that the normative exhausts

19 Austin (n 8) Lecture V, 184.

20 Hans Kelsen, Pure Theory of Law (Max Knight tr, 2nd edn, University of California Press 1967) Chapter I, § 1, 1 (emphasis original); cf Hans Kelsen, Introduction to the Problems of Legal Theory (Bonnie Litschewski Paulson and Stanley L. Paulson trs, Oxford University Press 1992) Chapter I, $\S 1,7$ : "The Pure Theory of Law is a theory of positive law, of positive law as such, and not of any special system of law. It is general legal theory, not an interpretation of particular national or international legal norms. / As theory, the Pure Theory of Law aims solely at cognition of its subject-matter, its object. It attempts to answer the questions of what the law is and how the law is made, not the questions of what the law ought to be or how the law ought to be made. The Pure Theory of Law is legal science, not legal policy." 
the content and nature of the law or alternately that the law is reduced to the prescriptive to the extent that "iniustia lex, non est lex", i.e. "unjust law is not law at all". ${ }^{21}$

As already advanced, I am especially interested in the possibility of connecting (1) and (2), on the one hand, and (3) and (4), on the other hand, and even the possibility of contrasting (1) and (3), on one side, and (2) and (4), on the other. Therefore, a legal theorist can not only be fixated in either describing and explaining or prescribing and justifying, or both; but also be focused in either what is common to all legal systems and cultures or what is specific of a particular legal system and culture, or both.

Actually, following Bentham's distinctions, nothing prevents a legal theorist from exposing first what is specific of a particular legal system or culture (3) and censoring it later (4). Analogously, also following Bentham, nothing precludes a legal theorist from exposing first what is common to all legal systems or cultures (1) and censoring it later (2). ${ }^{22}$ However, in the remainder of this section, we will bracket the former possibility and will focus on the latter possibility, i.e. the connection or not between (1) and (2).

In that sense, most legal positivists -following Austin, Kelsen and Hart- have insisted in the independence between (1) and (2) and have been claiming to be committed exclusively to (1) by suggesting that whenever the normative / justificatory dimension appears it is not longer law but morality what is at stake; and, hence, law can remain

21 See Saint Augustine of Hippo, On Free Choice of the Will (written in between 387-9 and 391-5, Thomas Williams tr, Hackett Publishing 1993) Book 1, 5, n. 11, 8: "an unjust law is not law at all"; cf Saint Thomas Aquinas, On Law, Morality and Politics (selections of Summa Theologica) (written in between 1265-74, Richard J. Reagan tr, Hackett Publishing 2002) Question 95 "On Human Law", Second Article "Is Every Human Law Derived form the Natural Law", 54: "Augustine says in his work On Free Choice: "Unjust laws do not seem to be laws".

22 See Bentham (n 16) Chapter XVII, §§ 21-9, pp. 293-300. 
Este libro forma parte del acervo de la Biblioteca Jurídica Virtual del Instituto de Investigaciones Jurídicas de la UNAM

\section{THE LEGACY OF RONALD DWORKIN}

morally neutral 23 or indirectly evaluative; ${ }^{24}$ and so have been labeled as "hard" or "exclusive legal positivists". Similarly, even those that admit that there are contingent relationships between (1) and (2) seem to subordinate (2) to (1), due to the fact that it is the law, which includes or incorporates references to morality, ${ }^{25}$ and even can be reduced accordingly to a mere or pure conceptual analysis without normative / justificatory aims, ${ }^{26}$ and so have been labeled as "soft", "inclusive legal positivists" or "incorporationists". Moreover, some legal positivists have conceded to different extent by recognizing the possibility ${ }^{27}$ and even the necessity $^{28}$ of connecting both (1) and (2). Finally, some natural law theorists, following Saint Thomas Aquinas dictum "Non

23 See Joseph Raz, Ethics in the Public Domain (Oxford University Press 1994); Andrei Marmor, Positive Law and Objective Value (Oxford University Press 2001); and Scott Shapiro, Legality (Harvard University Press 2011).

24 See Dickson (n 17).

25 See Jules L Coleman, The Practice of Principle. In Defense of a Pragmatist Approach (Oxford University Press 2001); and, Wilfrid J Waluchow, Inclusive Legal Positivism (Oxford University Press 1994).

26 See Kenneth E Himma, 'Reconsidering a Dogma: Conceptual Analysis, the Naturalistic Turn, and Legal Philosophy', in Ross Harrison (ed), Law and Philosophy: Current Legal Issues (Oxford University Press 2008); cf Andrei Marmor, 'Farewell to Conceptual Analysis (in Jurisprudence)', in Wil Waluchow and Stefan Sciaraffa (eds), Philosophical Foundations of The Nature of Law (Oxford University Press 2013); and, cf also Brian Leiter, Naturalizing Jurisprudence. Essays on American Legal Realism and Naturalism in Legal Philosophy (Oxford University Press 2007).

27 See Fred Schauer, 'Positivism as Pariah' in Robert P. George (ed), The Autonomy of Law. Essays on Legal Positivism (Oxford University Press 1996); Solum (n 17); and, Adrian Vermeule, 'Connecting Positive and Normative Legal Theory’ (2008) 10 University of Pennsylvania Journal Constitutional Law 387.

28 See Tom Campbell, The Legal Theory of Ethical Positivism (Ashgate 1996); Neil MacCormick, 'A Moralistic Case for A-Moralistic Law' (1985) 20 Valparaiso Law Review 1; Liam Murphy, 'The Political Question of the Concept of Law' in Jules L Coleman (ed), Hart's Postscript. Essays on the Postscript to the Concept of Law (Oxford University Press 2001); and, Jeremy Waldron, 'Normative (or Ethical) Positivism', in ibid. 
lex, sed legis corruptio" 29 seem to be adopting a form of weak natural law theory that connects both (1) and (2).

To conclude this section I will like to advance my claim that Dworkin's model is neither fixated in either describing and explaining or prescribing and justifying, but in both, nor focused in either what is common to all legal systems and cultures or what is specific of a particular legal system and culture, but in both. Let me clarify that Dworkin integrates (1), (2), (3) and (4) into a much more complex legal framework by combining the different possibilities or more precisely by blurring the lines dividing them. ${ }^{30}$

Keep in mind that Dworkin not only blurs the lines diving the different possibilities, i.e. general and particular, descriptive / explanatory and normative / justificatory but also collapses the distinctions between creation and application, between legislation and adjudication, and most notably between theory and practice. For example, in Law's Empire, Dworkin affirms: on one side, "Jurisprudence is the general part of adjudication, silent prologue to any decision at law";31 and, on the other, "Interpretative theories are by their nature addressed to a particular legal culture, generally the culture to which their authors belong". ${ }^{32}$

29 Aquinas (n 21) 54: "And a human law diverging in any way from the natural law will be a perversion of law and no longer a law"; cf John Finnis, Natural Law and Natural Rights (Oxford University Press 1980; 2nd edn, Oxford University Press 2011); and, Mark C. Murphy, 'The Explanatory Role of the Weak Natural Law Theory' in Waluchow and Sciaraffa (eds) (n 26).

30 I am grateful to Dan Priel who pointed out to me the importance of emphasizing the blurring of the lines dividing the different possibilities.

31 Dworkin, Law's Empire (n 5) 90; cf Duncan Kennedy, A Critique of Adjudication (fin de siècle) (Harvard University Press 1997) 30-8.

32 Ibid 102; see Ronald Dworkin, A Matter of Principle (Harvard University Press 1985); and, see also Ronald Dworkin, 'Legal Theory and the Problem of Sense' in Ruth Gavison (ed), Issues in Contemporary Legal Philosophy (Oxford University Press 1987). 
THE LEGACY OF RONALD DWORKIN

(1)

(3)

\section{Dworkin's Legal Theory and Methodology}

In this section, I will like to revisit some features of Dworkin's model, which we can characterize as being: a) constructive; b) interpretive (and even argumentative); c) evaluative; and d) integrative.

a) Constructive. Ever since the publication of his book review on John Rawls' A Theory of Justice in $1973^{33}$ and all the way to his Justice for Hedgehogs, ${ }^{34}$ Dworkin distanced himself from a "natural" model and endorsed a "constructive" one. The "natural" model presupposes a philosophical position that describes an objective moral reality, which is not created by human beings, but rather discovered by them, as the laws of physics: "Moral reasoning or philosophy is a process of reconstructing the fundamental principles by assembling concrete judgments in the right order, as a natural historian reconstructs the shape of the whole animal from the fragments of its bones that he has found." 35 On the contrary, the "constructive" model "treats intuitions of justice not as clues to the existence of independent principles, but rather as stipulated features of a general theory to be constructed, as if the sculptor set him-

33 Ronald Dworkin, 'The Original Position' (1973) 40 University of Chicago Law Review 500 (reprinted as 'Justice and Rights' in Dworkin (n 1) 150-83; references will be made to this version).

34 Dworkin, Justice for Hedgehogs (n 5) 63-6; see ibid 63: "moral judgments are constructed, not discovered: they issue from an intellectual device adopted to confront practical, not theoretical, problems."

35 Dworkin 'Justice and Rights' (n 33) 160. 
Este libro forma parte del acervo de la Biblioteca Jurídica Virtual del Instituto de Investigaciones Jurídicas de la UNAM

IMER B. FLORES

self to carve the animal that best fits a pile of bones he happened to find together". ${ }^{36}$ In his own voice: ${ }^{37}$

This 'constructive' model does not assume, as the natural model does, that principles of justice have some fixed, objective existence, so that descriptions of these principles must be true or false in some standard way. It does not assume that the animal it matches to the bones actually exists. It makes the different, and in some ways more complex, assumption that men and women have a responsibility to fit the particular judgments on which they act into a coherent program or action, or, at least, that officials who exercise power over other men have that sort of responsibility.

b) Interpretive. Later on, in his exchange with Stanley Fish on legal vis-à-vis literary interpretation ${ }^{38}$ and throughout his works, but especially in Law's Empire, ${ }^{39}$ Dworkin reinforces not only that the model is constructive and to some extent creative but clarifies that it is not inventive but interpretive of the practice. In other words, since law is an "interpretive concept" the proper method requires a "constructive interpretation" of the practice. In that sense, on one side, Dworkin is adamant in his criticism of "semantic theories of law", which he labels as "the semantic sting", be-

36 Ibid.

37 Ibid.

38 See Ronald Dworkin, 'Law as Interpretation' (1982) 9 Critical Inquiry 179 (reprinted in 60 Texas Law Review 527 (1982); in WJT Mitchell (ed), The Politics of Interpretation (Chicago University Press 1983); and revised as 'How Law Is Like Literature' in A Matter of Principle (n 32); references will be made to this version); and see also Ronald Dworkin, 'My Reply to Stanley Fish (and Walter Benn Michaels): Please Don't Talk about Objectivity Any More', in WJT Mitchell (ed) (n 38) (reprinted in an altered and abbreviated form as 'On Interpretation and Objectivity', in A Matter of Principle (n 32); references will be made to this version); cf Stanley Fish, 'Working on the Chain Gang: Interpretation in Law and Literature' (1982) 9 Critical Inquiry 201 (reprinted in 60 Texas Law Review 551; in WJT Mitchell (ed) (n 38); cf also Stanley Fish, 'Wrong Again' (1983) Texas Law Review 299.

39 See Dworkin, Law's Empire (n 5). 


\section{THE LEGACY OF RONALD DWORKIN}

cause they appear to consider the concept of law as a "criterial concept" 40 and even a "natural kind concept" 41 with necessary and sufficient conditions, whereas it is an "interpretive concept". ${ }^{42}$ And, on the other, firstly, defines: "constructive interpretation is a matter of imposing purpose on an object or practice in order to make of it the best possible example of the form or genre to which it is taken to belong." ${ }^{43}$ Secondly, delineates three stages of constructive interpretation: 44

First, there must be a "preinterpretive" stage in which the rules and standards taken to provide the tentative content of the practice are identified... Second, there must be an interpretive stage at which the interpreter settles on some general justification for the main elements of the practice identified at the preinterpretive stage... Finally, there must be a postinterpretive or reforming stage, at which he adjusts his sense of what the practice "really" requires so as better to serve the justification he accepts at the interpretive stage.

And, thirdly, insists that its nature is interpretive rather than inventive: "The justification need not fit every aspect

40 Ibid 31-44; Ronald Dworkin, Justice in Robes (Harvard University Press 2006) 9-12; and Dworkin, Justice for Hedgehogs (n 5) 158-9.

41 See Dworkin, Justice in Robes (n 40) 10; and Dworkin, Justice for Hedgehogs (n 5) 158-9.

42 See Dworkin, 'How Law Is Like Literature' (n 38) 146-8; Law's Empire (n 5) 45-96; Dworkin, Justice in Robes (n 40) 10-2; and Dworkin, Justice for Hedgehogs (n 5) 160-3, 403-5.

43 Dworkin, Law's Empire (n 5) 52; see ibid 90: "constructive interpretations... try to show legal practice as a whole in its best light, to achieve equilibrium between legal practice as they find it and the best justification of that practice." In that sense, Dworkin's interpretive model is not merely applicative but argumentative as well, see Imer B Flores, ‘¿Es el derecho un modelo aplicativo?' in Juan Federico Arriola Cantero and Víctor Rojas Amandi (eds.), La filosofía del derecho hoy (Porrúa 2010).

44 Dworkin, Law's Empire (n 5); cf Imer B Flores, 'Natalie Stoljar's Wishful Thinking and One Step Beyond: What Should Conceptual Legal Analysis Become?' (2012) 6 Problema. Anuario de Filosofia y Teoría del Derecho 81, 97. 
or feature of the standing practice, but it must fit enough for the interpreter to be able to see himself as interpreting that practice, not inventing a new one."45

c) Evaluative. Although in "How Law is Like Literature" Dworkin seemed to diminish the evaluative as well as the descriptive in the process of emphasizing the interpretative, at the end it was clear that he has been endorsing a moral reading of the practice, which requires references to value and even value judgments that are not subjective but objective. ${ }^{46}$ On the one hand, Dworkin affirmed: "propositions of law are not merely descriptive of legal history, in a straightforward way, nor are they simply evaluative in some way divorced from legal history. They are interpretive of legal history, which combines elements of both description and evaluation but is different from both." 47 On the other hand, he clarified (with the "rules of courtesy" as example) that

45 Dworkin, Law's Empire (n 5) 66; see ibid 67: "He also needs convictions about how far the justification he proposes at the interpretive stage must fit the standing features of the practice to count as an interpretation of it rather than the invention of something new." See also Dworkin, Justice in Robes (n 40) 15: "Any lawyer has built up, through education, training, and experience, his own sense of when an interpretation fits well enough to count as an interpretation rather than as an invention."

46 See Dworkin, A Matter of Principle (n 32); Dworkin, Law's Empire (n 5); Ronald Dworkin, Freedom's Law. The Moral Reading of the American Constitution (Harvard UP 1996), especially 'Introduction: The Moral Reading and the Majoritarian Premise' in ibid 1-38; Dworkin, Justice in Robes (n 40); and Dworkin, Justice for Hedgehogs (n 5); cf Imer B Flores, ¿¿Ensueño, pesadilla o realidad? Objetividad e (in)determinación en la interpretación del derecho' in Enrique Cáceres et al. (eds), Problemas contemporáneos de la filosofía del derecho (UNAM 2005) 185-92 and 192-4; and Imer B Flores, 'Legisprudence: The Role and Rationality of Legislators - vis-à-vis Judges - towards the Realization of Justice' (2009) 1:2 Mexican Law Review 91, 97-100; cf also Imer B Flores, 'The Living Tree: Fixity and Flexibility. A General Theory of (Judicial Review in a) Constitutional Democracy?' (2008) 2 Problema. Anuario de Filosofia y Teoría del Derecho 285; and Imer B Flores, 'The Living Tree Constitutionalism: Fixity and Flexibility' (2009) 3 Problema. Anuario de Filosofia y Teoría del Derecho 37.

47 Dworkin, 'How Law Is Like Literature' (n 38) 147. 
Este libro forma parte del acervo de la Biblioteca Jurídica Virtual del Instituto de Investigaciones Jurídicas de la UNAM

THE LEGACY OF RONALD DWORKIN

the "interpretive attitude" has two components, i.e. an assumption that it has an objective value (or point) and a further assumption that it is sensitive to it. In Dworkin's voice: 48

The first is the assumption that the practice of courtesy does not simply exist but has value, that it serves some interest or purpose or enforces some principle -in short, that it has some point - that can be stated independently of just describing the rules that make up that the practice. The second is the further assumption that the requirements of courtesy - the behavior it calls for or judgments it warrants - are not necessarily or exclusively what they have always been taken to be but are instead sensitive to its point, so that the strict rules must be understood or applied or extended or modified or qualified or limited by that point. Once this interpretive attitude takes hold, the institution of courtesy ceases to be mechanical; it is no longer unstudied deference to a runic order. People now try to impose meaning on the institution -to see its best light-and then to restructure it in the light of that meaning.

d) Integrative. In Law's Empire Dworkin advanced his conception of "law as integrity", which is highly dependent on the idea of coherence and fit, ${ }^{49}$ but in "Hart's Postscript

48 Dworkin, Law's Empire (n 5) 47 (emphasis original).

49 See ibid 94-6, especially 96: "[Law as integrity] argues that rights and responsibilities flow from past decisions and so count as legal, not just when they are explicit in these decisions but also when they follow from the principles of personal and political morality the explicit decisions presuppose by way of justification"; see also ibid, 176-224 and 225-75, especially 176: "We have two principles of political integrity: a legislative principle, which asks law makers to try to make the total set of laws morally coherent, and an adjudicative principle, which instructs that the law be seen as coherent in that way, so far as possible" (emphasis added); ibid 225: "Law as integrity denies that statements of law are either the backward-looking factual reports of conventionalism or the forward-looking instrumental programs of legal pragmatism. It insists that legal claims are interpretive judgments and therefore combine backward- and forward-looking elements; they interpret contemporary legal practice seen 
and the Character of Political Philosophy",50 Dworkin -by criticizing Hart's defense of an Archimedean jurisprudence- developed an argument against a detached conception of values and for an integrated conception of values. In a few words, Dworkin commences by affirming that "It would make a little sense to treat the political values... as detached values"; 51 continues by announcing that "political values are integrated rather than detached"52 and by asserting that "Law is a political concept";53 and, concludes by avowing that this project "must find the place of each value in a larger and mutually supporting web of conviction that displays supporting connections among moral and political

as an unfolding political narrative. So law as integrity rejects as unhelpful the ancient question whether judges find or invent law; we understand legal reasoning, it suggests, only by seeing the sense in which they do both and neither"; and, ibid 406: "We hope that our legislature will recognize what justice requires so that no practical conflict remains between justice and legislative supremacy; we hope that departments of law will be rearranged, in professional and public understanding, to map true distinctions of principle, so that local priority presents no impediment to a judge seeking a natural flow of principle throughout the law." cf Imer B Flores, 'The Quest for Legisprudence: Constitutionalism $v$. Legalism' in Luc J. Wintgens (ed), The Theory and Practice of Legislation: Essays on Legisprudence (Ashgate 2005) 35-8 and 43-7; Imer B Flores, 'Legisprudence: The Forms and Limits of Legislation' (2007) 1 Problema. Anuario de Filosofia y Teoría del Derecho 247, 257-60 and 264-6; and Flores (n 46) 100-6 and 106-9; cf also Imer B Flores, 'La cama o el lecho de Procrustes: Hacia una jurisprudencia comparada e integrada' (2008) Número Conmemorativo Sexagésimo Aniversario Boletín Mexicano de Derecho Comparado 273, 294-311; and Imer B Flores, 'The Problem about the Nature of Law vis-à-vis Legal Rationality Revisited: Towards an Integrative Jurisprudence', in Waluchow and Sciaraffa (n 26), 115-23.

50 See Ronald Dworkin, 'Hart's Postscript and the Character of Political Philosophy' (2004) 24 Oxford Journal of Legal Studies 1 (reprinted as 'Hart's Postscript and the Point of Political Philosophy' in Dworkin, Justice in Robes ( $\mathrm{n} 40$ ) references will be made to this version).

51 Ibid 158.

52 Ibid 159.

53 Ibid 162. 


\section{THE LEGACY OF RONALD DWORKIN}

values generally and then places these in the still larger context of ethics." 54

This claim, i.e. integrated values, advanced the thesis of the unity of value, which was proclaimed at the beginning of Justice for Hedgehogs "This book defends a large and old philosophical thesis: the unity of value",55 and is Dworkin response to the causes usually associated with foxes, i.e. value skepticism, subjectivism, relativism and pluralism. Nevertheless, let me reiterate that this thesis, in my opinion, can be traced all the way back to the early publication of "The Model of Rules I" in 1967: "[principles] have a dimension that rules do not - the dimension of weight or importance" and "principles rather hang together than link together [as rules do]". ${ }^{56}$

Furthermore, in the process of reinforcing his argument, Dworkin makes a dual claim for "independence of morality from science and metaphysics" (Hume's principle) and for "interdependence of morality and ethics" (Kant's principle). ${ }^{57}$ In a few words, Dworkin attacked the Archimedean epistemology and defended an integrated epistemology: "Our moral epistemology —our account of good reasoning about moral matters - must be an integrated rather than an Archimedean epistemology, and it must therefore be itself a substantive, first-order moral theory." ${ }_{58}$ Likewise, he

54 Ibid 168; see ibid 160: "must try to understand them holistically and interpretively, each in the light of the others, organized not in a hierarchy but in a fashion of a geodesic dome."

55 Dworkin, Justice for Hedgehogs (n 5) 1.

56 Dworkin, 'Model of Rules I' (n 5) 26 and 41; cf Imer B. Flores, 'Ronald Dworkin's Justice for Hedgehogs and Partnership Conception of Democracy (With a Comment to Jeremy Waldron's "A Majority in the Lifeboat")' (2010) 4 Problema. Anuario de Filosofia y Teoría del Derecho 65, 67-8 fn 4; and Imer B. Flores, 'Proportionality in Constitutional and Human Rights Interpretation' (2013) 7 Problema. Anuario de Filosofia y Teoría del Derecho 83, 99 fn 41.

57 Dworkin, Justice for Hedgehogs (n 5) 19.

58 Ibid 100; see ibid 82: "we must make assumptions about what is true in order to test theories about how to decide what is true." 
appealed not only to "the character of interpretation and of interpretive truth and the independence of both ethical and moral truth from science and metaphysics" but also to an "interpretive integration of ethics and morality".59

Finally, regarding law and morality, Dworkin, in an autobiographical paragraph in Chapter 19 of his Justice for Hedgehogs, acknowledged —or more precisely confessed: ${ }^{60}$

When more than forty years ago I first tried to defend interpretivism, I defended it within this orthodox two-systems picture. I assumed that law and morals are different systems of norms and that the crucial question is how to they interact. So I said... that the law includes not just enacted rules, or rules with pedigree, but justifying principles as well. I soon came to think, however, that the two-systems picture of the problem was itself flawed, and I began to approach the issue through a very different picture. I did not fully appreciate the nature of that picture, however, or how different it is from the orthodox model, until I began to consider the larger issues of this book.

So instead of considering law and morality as two separate systems, Dworkin has replaced it with a one-system picture, which now treats "law as a part of political morality" and recalled the aim of the book: "Our aim has been to integrate what are often taken to be separate departments of evaluation: we can easily place the doctrinal concept of law in that tree structure: law is a branch, a subdivision, of political morality."61 What's more Dworkin recognizes the existence of a difficult question and hints into its answer: "The more difficult question is how that concept [i.e. law] should be distinguished to show one as a distinct part of

59 Ibid 14; see Ronald Dworkin, Religion Without God (Harvard University Press 2013) 90.

60 Dworkin, Justice for Hedgehogs (n 5) 402 (internal references are omitted); cf Dworkin, 'Model of Rules I' (n 5) and 'Model of Rules II' (n 5).

61 Dworkin, Justice for Hedgehogs (n 5) 405. 
Este libro forma parte del acervo de la Biblioteca Jurídica Virtual del Instituto de Investigaciones Jurídicas de la UNAM

THE LEGACY OF RONALD DWORKIN

the other. Any plausible answer will center on the phenomenon of institutionalization."62

\section{Dworkin's One Right Answer Thesis Reconsidered}

To conclude I will like to briefly reconsider Dworkin's one right answer thesis in the light of his constructive, interpretive (and even argumentative), evaluative and integrative model. However, let me recall first its appearance and development.

At the core of his criticism of legal positivism, Dworkin cautioned: 63

To say that someone has a 'legal obligation' is to say that his case falls under a valid legal rule that requires him to do or to forbear form doing something. (To say he has a legal right, or has a legal power of some sort, or a legal privilege or immunity, is to assert, in a shorthand way, that other have an actual or hypothetical legal obligations to act or not to act in certain ways touching him.) In the absence of such a valid legal rule there is no legal obligation; it follows that when the judge decides an issue by exercising his discretion, he is not enforcing a legal right as to that issue.

According to this criticism, the judge that excercises discretion in hard cases is not applying the already existing law but acting as if he was the legislator to the extent of either creating new law or changing the existing one and what is even worse he is doing it ex post facto, which amounts to a violation of concrete principles such as the di-

62 Ibid; see Dworkin, Justice in Robes (n 40) 34-5: "We might treat law not as separate from but as a department of morality. We understand political theory that way: as part of morality more generally understood but distinguished, with its own distinct substance, because applicable to distinct institutional structures. We might treat legal theory as a special part of political morality distinguished by a further refinement of institutional structures."

63 Dworkin (n 1) 17. 
vision or separation of powers and the irretroactivity of the law and more abstract principles such as certainty, generality, legality, and normativity. On the contrary, Dworkin claims not only that the judge by appealing to the underlying justifying principles will still be applying already existing law without having to create new law or to change the existing one but also that there is and even must be one right answer to every legal question.

In the process of defending the one right answer thesis, ${ }^{64}$ on the one hand, in the center of "Hard Cases", Dworkin constructs an imaginary judge named Hercules: ${ }^{65}$

[A] lawyer of superhuman skill, learning, patience and acumen, whom I shall call Hercules... a judge in some representative American jurisdiction... [who] accepts the main uncontroversial constitutive and regulative rules of the law in his jurisdiction...that is, that statutes have the general power to create and extinguish legal rights, and that judges have the general duty to follow earlier decisions of their court or higher courts whose rationale... extends to the case at bar.

On the other hand, in the core of "Can Rights be Controversial?", continues with his defensive move: "My arguments suppose that there is often a single right answer to complex questions of law and political morality. The objection replies that there is sometimes no single right answer, but only answers."66

64 Although Stephen Guest used to emphasize that Dworkin's "one right answer" thesis was "purely defensive", I will like to suggest that Dworkin's defense became part of his offense as both the adagio "The best offense is a good defense" and the proverb "a meilleur défense c'est l'attaque", i.e. "attack is the best defense", suggest; see Stephen Guest, Ronald Dworkin (Stanford University Press 1992) 137-47, especially ibid 145: "Dworkin's thesis is... a defensive thesis to the criticism that there cannot be right answers in hard cases where there is no 'proof' or demonstration"; cf ibid (3rd edn, 2013) 135-43.

65 Dworkin, 'Hard Cases' (n 5) 105-6.

66 Dworkin (n 1) 279. 


\section{THE LEGACY OF RONALD DWORKIN}

Notwithstanding, by the time of the original publication of his "No Right Answer?", his defense is already part of his attack: "For all practical purposes, there will always be a right answer in the seamless web of our law." 67 Though this sentence does not appear in the version republished as "Is There Really No Right Answer in Hard Cases?",68 I am certain that Dworkin did not change his mind since, in 1996, in his "Objectivity and Truth: You'd Better Believe It", he insisted in his counter-attack: "This "no right answer" thesis cannot be true by default in law any more than in ethics or aesthetics or morals." 69 What's more, in Justice for Hedgehogs, Dworkin distinguished between indeterminacy and uncertainty: "But in all these aspects indeterminacy differs from uncertainty. "I am uncertain whether the proposition in question is true or false" is plainly consistent with "It is one or the other," but "The proposition in question is neither true nor false" is not."70

In a few words, Dworkin by differentiating indeterminacy from uncertainty, as he previously did by constructing Hercules, is able to separate the lack of certainty, i.e. a final demonstration or proof, from the claim for determinacy, i.e. a preexisting one right answer for every legal question being already somehow "out there". Let me clarify that "out there" in Dworkin's model means that the answer is, on the one hand, not to be discovered (or deducted) but to be constructed, from the already preexisting legal materials; and, on the other hand, not to be invented (or created and even

67 Ronald Dworkin, 'No Right Answer?' in PMS Hacker and J Raz (eds), Law, Morality and Society: Essays in Honour of H.L.A. Hart (Oxfor University Press 1977) 84.

68 See Ronald Dworkin, 'Is There Really No Right Answer in Hard Cases?' in A Matter of Principle (n 32).

69 Ronald Dworkin, 'Objectivity and Truth: You'd Better Believe It' (1996) 25 Philosophy and Public Affairs 87, 136.

70 Dworkin, Justice for Hedgehogs (n 5) 91; cf Imer B Flores, 'H.L.A. Hart's Moderate Indeterminacy Thesis Reconsidered: In Between Scylla and Charybdis?' (2011) 5 Problema. Anuario de Filosofia y Teoría del Derecho 147, 150-1 fn 3. 
changed) but to be interpreted (and even argued for), again from the already preexisting legal materials. Similarly, the one right answer thesis can be constructed and interpreted from the already preexisting legal materials because their objective value, i.e. interest, point or purpose, is evaluated according to the underlying principles, including moral ones, which not only justify the practice but also are integrated into law.

Against the critique that the preexisting legal materials may appear to be contradictory and even incommensurable, Dworkin provides an interpretation following his unity of value thesis that reconciles values by showing that moral conflict requires a deeper form of collaboration to solve the apparent conflict and even to figure out a point of comparison or contrast, to the extent that somehow the one right answer will despite all still be available even in very crazy cases. ${ }^{71}$ For that purpose Dworkin develops a variation of the drowning swimmer case, in which he first poses the problem and later reflects upon it: ${ }^{72}$

One person clings to a life preserver in a storm that has wrecked her boat; sharks circle her. Two other passengers cling to another life preserver a hundred yards away; sharks circle them as well. You have a boat on shore. You can reach one life preserver in time, but then not the other one. Assuming all three are strangers, do you have a duty to save the two swimmers and let the lone swimmer die?

$$
[\ldots]
$$

71 See Dworkin, Justice for Hedgehogs (n 5) 120; see also Ronald Dworkin's, Life's Dominion. An Argument about Abortion, Euthanasia, and Individual Freedom (Knopf 1993); cf Imer B Flores, 'Los dos conceptos de libertad: ¿Competición o colaboración?’ in Sergio Sarmiento (ed), Tercer Concurso de Ensayo "Caminos de la Libertad". Memorias (Grupo Salinas 2009).

72 Dworkin, Justice for Hedgehogs (n 5) 280-1; cf Lon L. Fuller, 'The Case of the Speluncean Explorers' (1949) 61 Harvard Law Review 616 (reprinted in (1999) 112 Harvard Law Review 1859). 


\section{THE LEGACY OF RONALD DWORKIN}

But if we approach the decision in another way - by concentrating not on consequences but on rights - it is far from plain that we should automatically save the greater number. We might think that each victim has an equal antecedent right to be saved, and we might therefore be tempted by a lottery in which each shipwreck victim has at least one-third chance to be saved. (The sharks agree to circle while the lottery is conducted.)

In sum, although most people will appear to be automatically inclined to save two, due to the bare fact that they are more than one, it is far from clear that that is a right answer. Actually, saving the greater number may seem to be the right answer from a consequentialist approach, but not according to a conception based on principles and values, in which each person has an equal antecedent right to be saved and must be treated with equal concern and respect, as Dworkin has been advocating throughout his works, ever since the publication of Taking Rights Seriously and all the way to Justice for Hedgehogs, including not only "Rights as Trumps" but also Sovereign Virtue. The Theory and Practice of Equality and Is Democracy Possible Here? Principles for a New Political Debate.73 In my opinion, all this reinforces the idea that the one right answer is already presupposed by the dworkinian model, which not only is constructive, interpretive (and even argumentative), evaluative and integrative, but also integrates among the preexisting legal materials the principles of human dignity with its corresponding rights and responsibilities.

73 See Dworkin (n 1); Ronald Dworkin, 'Rights as Trumps' in Jeremy Waldron (ed), Theories of Rights (Oxford University Press 1984); Ronald Dworkin, Sovereign Virtue. The Theory and Practice of Equality (Harvard University Press 2000); Ronald Dworkin, Is Democracy Possible Here? Principles for a New Political Debate (Princeton University Press 2006); and Dworkin, Justice for Hedgehogs (n 5); see also Ronald Dworkin, 'From Justice in Robes to Justice for Hedgehogs' (2015) 9 Problema. Anuario de Filosofia y Teoría del Derecho 3. 
IMER B. FLORES

\section{REFERENCES}

Aquinas Saint Thomas, On Law, Morality and Politics (selections of Summa Theologica) (written in between 1265-74, Richard J. Reagan tr, Hackett Publishing 2002).

Austin John, 'The Province of Jurisprudence Determined' (first published 1832) in The Province of Jurisprudence Determined and The Uses of the Study of Jurisprudence (Hackett Publishing 1998).

Bentham Jeremy, An Introduction to the Principles of Morals and Legislation (first published 1789, JH Burns and HLA Hart eds, Oxford University Press 1996).

A Fragment on Government (first published 1776, JH Burns and HLA Hart eds, Cambridge University Press 1988).

Bix Brian, Jurisprudence: Theory and Context (3 ${ }^{\text {rd }}$ edn, Sweet \& Maxwell 2003).

Campbell Tom, The Legal Theory of Ethical Positivism (Ashgate 1996).

Coleman Jules L, The Practice of Principle. In Defense of a Pragmatist Approach (Oxford University Press 2001).

Dickson Julie, Evaluation and Legal Theory (Hart Publishing 2001).

Dworkin Ronald, 'The Model of Rules' (1967) 35 University of Chicago Law Review 14.

_ 'Social Rules and Legal Theory' (1972) 81 Yale Law Journal 855.

'The Original Position' (1973) 40 University of Chicago Law Review 500.

'Hard Cases' (1974) 88 Harvard Law Review 1057. 


\section{THE LEGACY OF RONALD DWORKIN}

'No Right Answer?' in PMS Hacker and J Raz (eds), Law, Morality and Society: Essays in Honour of H.L.A. Hart (Oxford University Press 1977).

Taking Rights Seriously (Harvard University Press \& Duckworth 1977; 2nd edn 'with an "Appendix: A Reply to Critics"', Harvard University Press \& Duckworth 1978) vii.

'Law as Interpretation' (1982) 9 Critical Inquiry 179 (reprinted in 60 Texas Law Review 527 (1982) in WJT Mitchell (ed), The Politics of Interpretation (Chicago University Press 1983); and revised as 'How Law Is Like Literature' in A Matter of Principle.

'My Reply to Stanley Fish (and Walter Benn Michaels): Please Don't Talk about Objectivity Any More', in WJT Mitchell (ed), The Politics of Interpretation (Chicago University Press 1983).

'Rights as Trumps' in Jeremy Waldron (ed), Theories of Rights (Oxford University Press 1984).

A Matter of Principle (Harvard University Press 1985).

Law's Empire (Harvard University Press 1986).

'Legal Theory and the Problem of Sense' in Ruth Gavison (ed), Issues in Contemporary Legal Philosophy (Oxford University Press 1987).

- Life's Dominion. An Argument about Abortion, Euthanasia, and Individual Freedom (Knopf 1993).

'Objectivity and Truth: You'd Better Believe It' (1996) 25 Philosophy and Public Affairs 87.

Sovereign Virtue. The Theory and Practice of Equality (Harvard University Press 2000).

'Hart's Postscript and the Character of Political Philosophy' (2004) 24 Oxford Journal of Legal Studies.

- Is Democracy Possible Here? Principles for a New Political Debate (Princeton University Press 2006). 
IMER B. FLORES

Justice in Robes (Harvard University Press 2006).

- Justice for Hedgehogs (Harvard University Press 2011).

Religion Without God (Harvard University Press 2013).

'From Justice in Robes to Justice for Hedgehogs' (2015) 9 Problema. Anuario de Filosofia y Teoría del Derecho.

Finnis John, Natural Law and Natural Rights (Oxford University Press 1980; 2nd edn, Oxford University Press 2011).

Fish Stanley, 'Working on the Chain Gang: Interpretation in Law and Literature' (1982) 9 Critical Inquiry.

'Wrong Again' (1983) Texas Law Review.

Flores Imer B, ‘¿Ensueño, pesadilla o realidad? Objetividad e (in)determinación en la interpretación del derecho' in Enrique Cáceres et al. (eds), Problemas contemporáneos de la filosofía del derecho (UNAM 2005).

'The Quest for Legisprudence: Constitutionalism $v$. Legalism' in Luc J. Wintgens (ed), The Theory and Practice of Legislation: Essays on Legisprudence (Ashgate 2005).

'Legisprudence: The Forms and Limits of Legislation' (2007) 1 Problema. Anuario de Filosofia y Teoría del Derecho.

'La cama o el lecho de Procrustes: Hacia una jurisprudencia comparada e integrada' (2008) Número Conmemorativo Sexagésimo Aniversario Boletín Mexicano de Derecho Comparado.

'The Living Tree: Fixity and Flexibility. A General Theory of (Judicial Review in a) Constitutional Democracy?' (2008) 2 Problema. Anuario de Filosofia y Teoría del Derecho. 
'Legisprudence: The Role and Rationality of Legislators -vis-à-vis Judges - towards the Realization of Justice' (2009) 1:2 Mexican Law Review.

'Los dos conceptos de libertad: ¿Competición o colaboración?' in Sergio Sarmiento (ed), Tercer Concurso de Ensayo "Caminos de la Libertad". Memorias (Grupo Salinas 2009).

'The Living Tree Constitutionalism: Fixity and Flexibility' (2009) 3 Problema. Anuario de Filosofía y Teoría del Derecho.

‘¿Es el derecho un modelo aplicativo?' in Juan Federico Arriola Cantero and Víctor Rojas Amandi (eds), La filosofía del derecho hoy (Porrúa 2010).

'Ronald Dworkin's Justice for Hedgehogs and Partnership Conception of Democracy (With a Comment to Jeremy Waldron's "A Majority in the Lifeboat")' (2010) 4 Problema. Anuario de Filosofia y Teoría del Derecho.

'HLA Hart's Moderate Indeterminacy Thesis Reconsidered: In Between Scylla and Charybdis?' (2011) 5 Problema. Anuario de Filosofía y Teoría del Derecho.

'Natalie Stoljar's Wishful Thinking and One Step Beyond: What Should Conceptual Legal Analysis Become?' (2012) 6 Problema. Anuario de Filosofia y Teoría del Derecho.

'Proportionality in Constitutional and Human Rights Interpretation' (2013) 7 Problema. Anuario de Filosofía y Teoría del Derecho.

Fuller Lon L, 'The Case of the Speluncean Explorers' (1949) 61 Harvard Law Review 616 (reprinted in (1999) 112 Harvard Law Review 1859).

Guest Stephen, Ronald Dworkin (Stanford University Press 1992). 
Hart HLA, The Concept of Law (Oxford University Press 1961; 2nd edn 'With a "Postscript" edited by Penelope A. Bulloch and Joseph Raz', Oxford University Press 1994; and $3^{\text {rd }}$ edn 'With an "Introduction and Notes" by Leslie Green', Oxford University Press 2012).

L Law, Liberty and Morality (Stanford University Press, 1963).

- Punishment and Responsability. Essays in the Philosophy of Law (Oxford University Press 1968).

Essays on Bentham. Jurisprudence and Political Theory (Oxford University Press 1982).

Essays in Jurisprudence and Philosophy (Oxford University Press 1983).

Himma Kenneth E, 'Reconsidering a Dogma: Conceptual Analysis, the Naturalistic Turn, and Legal Philosophy', in Ross Harrison (ed), Law and Philosophy: Current Legal Issues (Oxford University Press 2008).

Saint Augustine of Hippo, On Free Choice of the Will (written in between 387-9 and 391-5, Thomas Williams tr, Hackett Publishing 1993).

Kelsen Hans, Pure Theory of Law (Max Knight tr, 2nd edn, University of California Press 1967).

Introduction to the Problems of Legal Theory (Bonnie Litschewski Paulson and Stanley L. Paulson trs, Oxford University Press 1992).

Kennedy Duncan, A Critique of Adjudication (fin de siècle) (Harvard University Press 1997).

Lacey Nicola, A Life of H.L.A. Hart. The Nightmare and the Noble Dream (Oxford University Press 2004).

Leiter Brian, Naturalizing Jurisprudence. Essays on American Legal Realism and Naturalism in Legal Philosophy (Oxford University Press 2007). 


\section{THE LEGACY OF RONALD DWORKIN}

MacCormick Neil, 'A Moralistic Case for A-Moralistic Law' (1985) 20 Valparaiso Law Review.

Marmor Andrei, Positive Law and Objective Value (Oxford University Press 2001).

'Farewell to Conceptual Analysis (in Jurisprudence)', in Wil Waluchow and Stefan Sciaraffa (eds), Philosophical Foundations of The Nature of Law (Oxford University Press 2013).

Murphy Liam, 'The Political Question of the Concept of Law' in Jules L Coleman (ed), Hart's Postscript. Essays on the Postscript to the Concept of Law (Oxford University Press 2001).

Murphy Mark C., 'The Explanatory Role of the Weak Natural Law Theory', in Wil Waluchow and Stefan Sciaraffa (eds), Philosophical Foundations of The Nature of Law (Oxford University Press 2013).

Priel Dan, 'Jurisprudential Disagreements and Descriptivism' (2014) 8 Problema. Anuario de Filosofia y Teoría del Derecho.

Raz Joseph, Ethics in the Public Domain (Oxford University Press 1994).

Ripstein Arthur, 'Normative and Analytic Jurisprudence', in IVR Encyclopaedia of Jurisprudence, Legal Theory and Philosophy of Law http://www.ivr-enc.info/index. php?title=Normative_and_Analytic_Jurisprudence accessed 14 November 2014.

Shapiro Scott, Legality (Harvard University Press 2011).

Schauer Fred, 'Positivism as Pariah' in Robert P. George (ed), The Autonomy of Law. Essays on Legal Positivism (Oxford University Press 1996).

Solum Larry, 'Legal Theory Lexicon 016: Positive and Normative Legal Theory', in Legal Theory Lexicon http://1solum.typepad.com/legal_theory_lexic 
on/2003/12/legal_theory_le.html accessed 14 November 2014 .

- 'Legal Theory Lexicon 044: Legal Theory, Jurisprudence, and the Philosophy of Law', in Legal Theory Lexicon http://1solum.typepad.com/legal_theory_lexi con/2003/44/legal_theory_le.html and http://le galtheorylexicon.blogspot.com/2005/05/legal-theor y-lexicon-044-legal-theory.html accessed 14 November 2014.

Vermeule Adrian, 'Connecting Positive and Normative Legal Theory' (2008) 10 University of Pennsylvania Journal of Constitutional Law.

Waluchow Wilfrid J, Inclusive Legal Positivism (Oxford University of Pennsylvania Journal of Constitutional Law 1994). 